\title{
Herbaceous Restoration of Juniper Dominated Grasslands With Chaining and Fire
}

\author{
R. J. Ansley, ${ }^{1}$ H. T. Wiedemann, ${ }^{2}$ M. J. Castellano, ${ }^{3}$ and J. E. Slosser ${ }^{4}$ \\ Authors are ${ }^{1}$ Professor, ${ }^{2}$ Professor Emeritus, ${ }^{3}$ Research Associate, and ${ }^{4}$ Professor and Regents Fellow, \\ Texas Agricultural Experiment Station, PO Box 1658, Vernon, TX 76384.
}

\begin{abstract}
Juniper (Juniperus spp.) encroachment in grasslands usually progresses toward a stable woody state of mature trees that requires a significant disturbance to shift succession in another direction. Fire alone is often inadequate to shift succession in dense stands of mature juniper and must be preceded by a mechanical treatment such as chaining to reduce juniper competition and increase herbaceous growth that fuels a subsequent fire. However, little long-term data are available that measure combined effects of mechanical and fire treatments on restoration of juniper-dominated grasslands. Here, on a degraded $(40 \%$ bare ground) north Texas site dominated by redberry juniper (Juniperus pinchotii Sudw), we quantify long-term herbaceous responses to mechanical chaining followed by fire. Two types of chaining, ground-level and elevated, were evaluated and all chained plots were burned 4 years after chaining. Herbaceous and woody responses were measured for several years after both chaining and fire treatments and compared to untreated controls. At study termination, both of the chaining + fire treatments reduced juniper cover from $32 \%$ to $<6 \%$, but mortality was $<10 \%$, because most plants basal-sprouted. Total grass production did not increase in chained treatments over the untreated until 3 growing seasons after chaining. Grass production declined the first growing season following the fire treatment, but increased in treated plots to 3 times the untreated the second and third year postfire. Total grass cover in treated plots did not increase over the untreated until the second year after the fire treatment. There was no difference in juniper or herbaceous responses between the 2 chain types. Results suggest increases in herbaceous production from chaining alone were due to increased growth of existing vegetation patches whereas the fire treatment appeared to stimulate herbaceous recruitment into bare soil areas.
\end{abstract}

\section{Resumen}

La invasión de "Juniper" (Juniperus spp.) en los pastizales generalmente progresa hacia un estado estable de plantas leñosas de árboles maduros que requieren de un disturbio significativo para desviar la sucesión hacia otra dirección. El fuego solo a menudo es inadecuado en poblaciones densas de "Juniper" maduros y debe ser precedido por un tratamiento mecánico, tal como el cadeneo, para reducir la competencia del "Juniper" e incrementar el crecimiento de las herbáceas que servirán de combustible para el fuego subsiguiente. Sin embargo, son pocos los datos de largo plazo disponibles que miden los efectos combinados de los tratamientos mecánicos y fuego en la restauración de pastizales dominados por "Juniper". Aquí, en un sito degradado ( $40 \%$ de suelo desnudo) del norte de Texas dominado por "Redberry juniper" (Juniperus pinchotii Sudw), cuantificamos la respuesta a largo plazo de las herbáceas al cadeneo mecánico seguido por fuego. Se evaluaron dos tipos de cadeneo, a nivel de suelo y elevado, y todas las parcelas cadeneadas fueron quemadas 4 años después del cadeneo. La respuesta de especies herbáceas y leñosas fueron medidas por varios años después de aplicados los tratamientos de cadeneo y fuego y comparadas con parcelas control sin tratar. Al terminar el estudio, ambos tratamientos de cadeneo + fuego redujeron la cobertura del "Juniper" de 32 a $<6 \%$, pero la mortalidad fue $<10 \%$, ya que la mayoría de las plantas tuvieron rebrote basal. La producción total de zacates de las parcelas tratadas con cadeneo no se incrementó inmediatamente en comparación con las parcelas control, sino hasta 3 estaciones de crecimiento después del cadeneo. La producción de zacates disminuyo en la primer estación de crecimiento después del tratamiento de fuego, pero en la segunda y tercer estaciones de crecimiento se incrementó en 3 veces de lo producido por las parcelas sin tratar. La cobertura total de zacates en las parcelas tratadas se incremento con respecto a las parcelas sin tratar hasta la segunda estación de crecimiento después de aplicado el fuego. No hubo diferencia en la respuesta del "Juniper" y las herbáceas a los dos tipos de cadeneo. Los resultados sugieren que los incrementos en la producción herbácea en el cadeneo solo se debieron a un aumento del crecimiento de parches de vegetación existentes mientras que el tratamiento fuego pareció estimular el establecimiento de herbáceas en áreas de suelo desnudo.

Key Words: brush management, herbaceous production, Juniperus pinchotii, mechanical treatment, prescribed fire, rangeland restoration, redberry juniper, woody plant encroachment

\section{INTRODUCTION}

Correspondence: R. J. Ansley, Texas Agricultural Experiment Station, P0 Box 1658, Vernon, TX 76384. Email: r-ansley@tamu.edu

Manuscript received 21 May 2005; manuscript accepted 27 October 2005.
Woody plants have encroached in many grassland and savanna ecosystems worldwide during recent history and continue to expand (Hodgkinson and Harrington 1985; Grover and $\mathrm{Mu}-$ sick 1990; Van Auken 2000). Woody encroachment ultimately 
decreases herbaceous production and diversity, reduces wildlife habitat, and increases bare ground and soil erosion potential (Scholes and Archer 1997). Although woody encroachment occurs globally and includes many species, geographically distant ecosystems suffer similar deleterious effects (Asner et al. 2004).

Increases in woody plant encroachment are attributed to fire suppression, livestock overgrazing of herbaceous species, enhanced seed distribution via livestock or wildlife, and climate change (Kramp et al. 1998; Van Auken 2000). Overgrazing by livestock has the dual effect of weakening the competitive ability of grasses against emerging woody plant seedlings as well as reducing the amount of herbaceous fine fuel that normally supports fires (Archer et al. 1995; Miller and Rose 1999).

Woody plant dominance in grasslands is often considered a "stable state" because when a threshold of woody encroachment is attained, the change in dominant vegetation may be irreversible without a major disturbance or anthropogenic inputs (i.e., prescribed fire and/or mechanical or chemical inputs) to destroy the woody canopies (Archer 1990; Miller et al. 2000). Resource managers worldwide are recognizing the need for such inputs, often involving combinations of treatments, to restore grasslands and savannas from woodlands (Noble et al. 1991; Holmes et al. 2000).

Junipers (Juniperus spp.), woody shrubs native to North America, have expanded beyond their historical ranges since the late 1800s in the desert southwest (Johnson 1962), intermountain west (Burkhardt and Tisdale 1976; Miller and Rose 1999), and Great Plains (Gehring and Bragg 1992). Junipers have encroached upon over 10 million ha of grasslands in the southern prairie states of Texas and Oklahoma (Engle 1985; Ansley et al. 1995; Ueckert et al. 2001). Juniper-encroached grasslands provide a robust example of a woodland stable state. Because junipers are evergreens with dense foliage and shallow root systems, their negative impact on the herbaceous understory and soil erosion is particularly severe (McPherson and Wright 1990; Miller et al. 2000; Ansley and Rasmussen 2005). Herbaceous production often declines significantly with as little as $10 \%-20 \%$ of juniper canopy cover, similar to regrowth Eucalyptus in Australia (Watson and Reid 2001). This differs from herbaceous responses to other woody species worldwide such as Prosopis and Acacia that have more open canopies and are more associated with savanna physiognomies where grass production is not reduced until woody cover exceeds 20\%-30\% (Belsky 1994; Scholes and Archer 1997; Ansley et al. 2004).

Prescribed burning has been used to reestablish fire disturbance regimes more characteristic of grasslands and restore herbaceous dominance (Wright and Bailey 1982; Steuter and Britton 1983). Fires are most effective during the early stages of juniper encroachment when juniper size and densities are low and the grassland community supports a fine fuel (i.e., herbaceous biomass) component adequate to support a fire (Ansley and Rasmussen 2005). However, because mature juniper severely decreases herbaceous production, it is difficult to carry a fire through mature juniper stands. Thus, dense stands of mature junipers are often mechanically felled to reduce juniper competition and increase the herbaceous growth and dead woody debris that fuels a subsequent fire (Wink and Wright
1973; Steuter and Wright 1983). A similar strategy using an expensive treatment followed by fire has been employed for other woody encroached ecosystems in Australia (Noble et al. 1991; Weston and Attiwill 1996; Paynter and Flanagan 2004), but such practices have received limited attention in Africa because of the high relative cost of the mechanical treatment (Holmes et al. 2000).

Chaining is a common mechanical treatment utilized to fell mature juniper trees (Wiedemann 2004). Depending on terrain and tree size, one-direction chaining may cost from \$37$\$ 112 \mathrm{ha}^{-1}$ (\$15-\$45 $\mathrm{ac}^{-1}$ ) (Johnson et al. 1999; J. R. Conner, personal communication, 2005). Although chaining is typically conducted at ground level, Wiedemann and Cross (1996) determined that an elevated chaining technique could reduce pulling requirements of individual juniper trees while maintaining treefelling efficacy similar to that of ground-level chaining. The elevated chain is supported by a $1.2-\mathrm{m}$-diameter metal ball with an axle extending through the center that allows the ball to rotate as the unit is pulled by chains attached to each end of the axle (Wiedemann 2004). Ground-level chaining may have greater potential for damaging herbaceous plants and soil crusts and spreading undesirable plants such as prickly pear cactus (Opuntia spp.) than does an elevated chain (Rippel et al. 1983). Conversely, the scraping action of a ground level chain may improve seedbed conditions on smooth soil surfaces and thus help accelerate recruitment of herbaceous species.

In many studies, the vegetative responses of juniper to fire or chaining alone have been observed (Tausch and Tueller 1977; Steuter and Britton 1983; Barnitz et al. 1990), but few have quantified combined effects of mechanical + fire treatments on dense juniper stands over long enough time periods to include responses to each treatment (Steuter and Wright 1983; Ansley and Rasmussen 2005). Thus, there is a need to quantify the long-term effects of such combined treatments for juniper control and herbaceous restoration. In addition, little is known regarding the effect of precipitation on herbaceous recovery rates following treatment of the woody overstory.

Many grassland areas of the southern Great Plains (United States) are dominated by redberry juniper (Juniperus pinchottii Sudw.). This species is particularly difficult to control because, unlike most juniper species, it sprouts from stem bases following aboveground disturbances (Steuter and Wright 1983). Moreover, dense stands of redberry juniper support the biting horse fly (Tabanus abacter Philip) that causes significant economic loss to livestock operations (Wiedemann et al. 2005). The objectives of this study were 1) to quantify the effect of 2 types of chaining (ground-level and elevated), each followed by fire 4 years later, on herbaceous restoration in redberry juniper dominated rangelands and 2) relate herbaceous recovery rate to posttreatment precipitation patterns. We hypothesized that 1) both ground-level chain + fire and elevated chain + fire treatments would facilitate herbaceous restoration by increasing grass production and cover, and decreasing bare ground, 2) elevated chaining would accelerate herbaceous restoration compared to ground-level chaining because of less physical damage to herbaceous plants and soils, and 3) herbaceous response to precipitation would differ between treated and untreated juniper stands. 


\section{MATERIALS AND METHODS}

\section{Study Area and Treatments}

The study occurred on 2 ranches $15 \mathrm{~km}$ apart in northwest Texas (lat $33^{\circ} 59^{\prime} \mathrm{N}$, long $99^{\circ} 50^{\prime} \mathrm{W}$ and lat $33^{\circ} 50^{\prime} \mathrm{N}$, long $99^{\circ} 48^{\prime} \mathrm{W}$ ) south of Crowell, Texas. Soils at both sites were complexes of the Cottonwood (silt loam; thermic Lithic Ustorthents), Talpa (loam; thermic Lithic Calciustolls), and Knoco (clay loam; thermic shallow Aridic Ustorthents) soil series (Natural Resource Conservation Service office, Vernon, TX). Soils were badly eroded, and there was evidence from the observation of exposed root systems of juniper plants that as much as $0.5 \mathrm{~m}$ of soil had been lost to erosion in the last 50-100 years. Mean annual precipitation is $630 \mathrm{~mm}$ with most occurring between April and October (NOAA 2003). Herbaceous vegetation at both ranch locations was dominated by $\mathrm{C}_{4}$ (warm-season) perennial grasses, including sideoats grama (Bouteloua curtipendula [Michx.] Torr.), tobosagrass (Hilaria mutica [Buckl.] Benth), buffalograss (Buchloe dactyloides [Nutt.] Engelm.), and silver bluestem (Bothroichloa laguroides [DC.] Herter. Subspp torreyana [Steud.]). Also present was the $\mathrm{C}_{3}$ (cool-season) perennial Texas wintergrass (Nassella leucotricha Trin. and Rupr.). There were numerous forb species but none occurring in great quantities.

The study had 3 treatments with 4 replicate plots per treatment (2 replicates per ranch). Treatments were 1) untreated control, 2) ground-level chaining followed by fire 4 years later $(\mathrm{GLC}+\mathrm{F})$, and 3$)$ elevated chaining followed by fire 4 years later $(\mathrm{EC}+\mathrm{F})$. Plot size ranged from $12-17$ ha. A dense stand of redberry juniper, $32 \%$ cover, occurred in each plot prior to treatments.

Chaining was conducted in March 1997. Two crawler tractors pulled $54 \mathrm{~m}$ of 52-mm-diameter anchor chain for ground-level chaining. For the elevated chaining treatment, an anchor chain was suspended between a 1.2-m-diameter steel ball located in the center of the chain and the 2 crawlers such that the average striking height of the chain was $0.6 \mathrm{~m}$ above ground. Chaining rate was measured with a stopwatch for each plot, and production (ha chained $\cdot \mathrm{hr}^{-1}$ ) was calculated based on time and measured plot acreage. Chaining rates were not significantly different between the 2 chain types and averaged $9.2 \mathrm{ha} \cdot \mathrm{hr}^{-1}$, and chaining cost was estimated at $\$ 27 \mathrm{ha}^{-1}$ (see Wiedemann et al. 2005 for details).

Fires were applied as head fires, following guidelines by Wright and Bailey (1982), in February and early March 2001, 4 years after the chaining treatments. Plots were burned as individual units with a total of 8 plots burned $(4$ reps $\times 2$ treatments). Air temperature, relative humidity $(\mathrm{RH})$, and wind speed just prior to the fires averaged $18.5^{\circ} \mathrm{C}, 40.1 \%$, and $4.8 \mathrm{~m} \cdot \mathrm{s}^{-1}$, respectively. Herbaceous fine fuel averaged $990 \mathrm{~kg} \cdot \mathrm{ha}^{-1}$ (range 800-1100) over all burn plots. Fire intensity, based on flame length, was low to moderate (R. J. Ansley, personal observation, 2001) because droughts in 1998, 2000, and 2001 limited herbaceous fine fuel accumulation. However, low fuel moisture content from the droughts helped offset the low fuel quantities and increased fire intensity.

\section{Vegetation and Precipitation Measurements}

Pretreatment juniper canopy cover, density, and tree height were sampled at $15-\mathrm{m}$ spacing along a single $400-\mathrm{m}$ line oriented diagonally in each plot in 1996 (pretreatment) and 2003 using the point-center-quarter (PCQ) method (Bonham 1989). The PCQ method was applied at each of 25 points along each line. Distance from point to nearest tree and height of nearest tree in each quarter at each point was measured. Mortality of mature juniper trees was measured in late 1997, 8 months following chaining, and in 2003, 2 years after the fire treatment. At least 100 trees were evaluated within a $10-\mathrm{m}$ wide belt-transect along a diagonal line across each chained plot. A few stems that were detached and dragged away from tree crowns by chaining were treated as debris and not counted as part of the evaluation. In addition, newly emerging juniper plants that germinated after treatments were not counted in the mortality evaluations. Only the stumps of mature trees were evaluated as to whether they had live growth (either portions of original canopies or basal regrowth) or were completely dead.

Grass and forb standing crop (live + dead) and composition of herbaceous vegetation (grasses and forbs) was measured pretreatment in April 1996 and at the end of each growing season (1997-2003) along 2 parallel 300-m-long transects in each plot. At 20-m intervals along each transect, percent basal cover of each herbaceous species, percent bare ground, and percent litter cover were visually estimated within a $0.25-\mathrm{m}^{2}$ quadrat. Herbaceous standing crop within each $0.25-\mathrm{m}^{2}$ quadrat was then clipped to ground level and weighed after ovendrying at $60^{\circ} \mathrm{C}$ for 48 hours. Cover values were subsequently grouped into 8 functional groups: $C_{3}$ annual grasses, $C_{3}$ perennial midgrasses, $\mathrm{C}_{4}$ annual grasses, $\mathrm{C}_{4}$ perennial midgrasses, $\mathrm{C}_{4}$ perennial short grasses, forbs, litter, and bare ground.

Livestock grazing was removed on both sites from April 1996 to April 2001. Two months after the 2001 fires, the ranch owners were forced to reintroduce grazing because of the drought. Therefore, 16, $1 \times 1-\mathrm{m}$ areas were protected in each plot by wire cages to maintain ungrazed sampling of standing crop and cover throughout the study.

Precipitation was recorded at both ranch sites during the study period using tipping bucket rain gauges. Annual precipitation totals were similar for both ranches and reported values are the average of the 2 ranch sites.

\section{Statistical Analyses}

A repeated measures randomized block design was used to determine main effects of treatment (untreated, GLC $+\mathrm{F}$, $\mathrm{EC}+\mathrm{F}$ ) and years on herbaceous vegetation responses with 4 replicate plots per treatment. Significant treatment $\times$ year interactions were analyzed within year using a general linear model procedure (SAS 1988) analysis of variance with a protected least significant difference method of means separation with significance level established at $P<0.05$. However, in some instances, important trends were also noted where $P$ was between 0.05 and 0.10 . Appropriate error terms were used for each main effect and their interactions with the pooled error used to test effect of year.

To address hypothesis 3, regression analysis was performed to determine the effect of annual precipitation on total grass standing crop in untreated compared to chain + fire treatment (GLC $+\mathrm{F}$ and $\mathrm{EC}+\mathrm{F}$ combined). Treatment implementation years, 1997 (chain) and 2001 (fire), were excluded from the regression. 


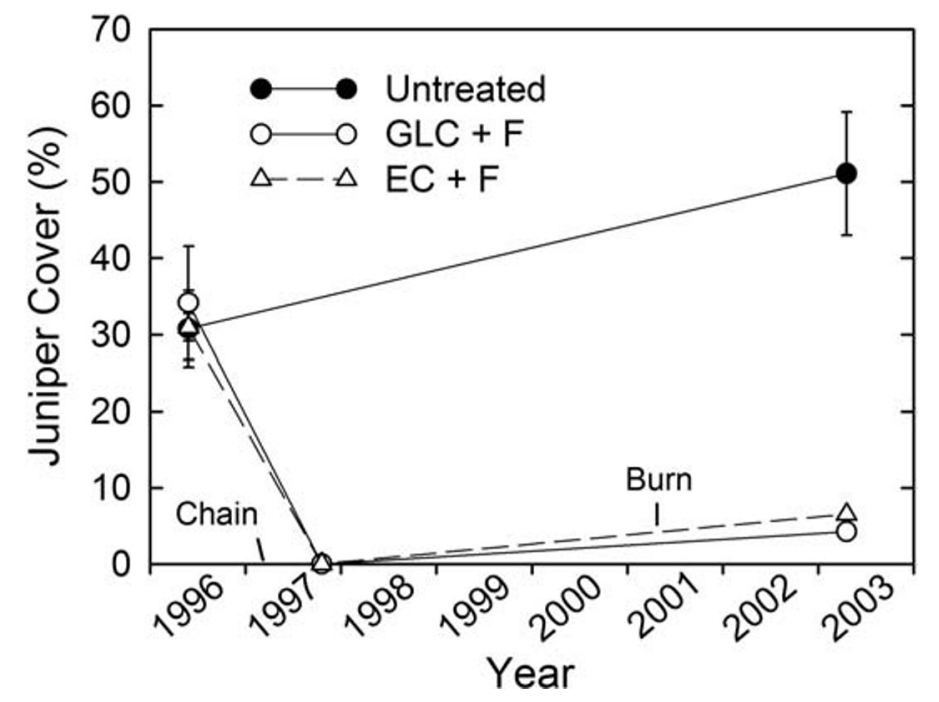

Figure 1. Redberry juniper canopy cover in response to the 3 treatments (Untreated; GLC $+\mathrm{F}=$ ground-level chain + fire; $\mathrm{EC}+\mathrm{F}=$ elevated chain + fire). Vertical bars are \pm 1 standard error.

\section{RESULTS}

\section{Chaining Efficiency and Juniper Responses}

Pretreatment juniper percent cover, density, and height were not significantly different between the 3 treatments and averaged $31.6 \%$ (range 30.3 to 34.3 ), 294 trees $\cdot$ ha $^{-1}$ (range 279 to 325 ), and $2.8 \mathrm{~m}$ (range 2.7 to 2.8 ), respectively. Both groundlevel and elevated chaining treatments reduced juniper canopy cover to $<1 \%$ (Fig. 1) and juniper tree height from $2.8 \mathrm{~m}$ to $<1.0 \mathrm{~m}$ (range 0.9 to 1.0 ). By 2003, 2 years after the fire treatments were imposed, juniper regrowth had increased canopy cover in the GLC $+\mathrm{F}$ and $\mathrm{EC}+\mathrm{F}$ treatments to $4 \%$ and $6 \%$, respectively, which were both significantly less than the untreated. Juniper canopy cover increased in untreated from $30 \%$ to $51 \%$ (1996 to 2003). Juniper mortality in 1997,8 months postchaining, was $19.2(\mathrm{SE}=1.4)$ and $20.5 \%(2.0)$ for EC and GLC, respectively. However, by 2003, 6 years postchaining and 2 years after the fire treatment, mortalities were 7.9 (2.2) and 4.4 (1.1) in GLC + F and EC + F treatments, respectively, suggesting some original old-growth plants that were counted as dead in 1997 from chaining alone had subsequently sprouted.

\section{Precipitation}

Annual precipitation was near the long-term average in 1997, 1999, and 2000 and well above average in 2002 (Fig. 2). Drought conditions prevailed in 1996, 1998, 2001, and 2003. Droughts in 1998 and 2001 were especially severe with very little precipitation occurring during the growing season.

\section{Herbaceous Standing Crop}

Pretreatment grass standing crop ranged from 56 to $80 \mathrm{~g} \cdot \mathrm{m}^{-2}$ in all treatments. In the year following chaining treatments, grass standing crop decreased to a greater degree relative to pretreatment levels in the ground-level chain treatment than in the other treatments (Fig. 2). Grass standing crop showed a trend of increasing in both chained treatments over the
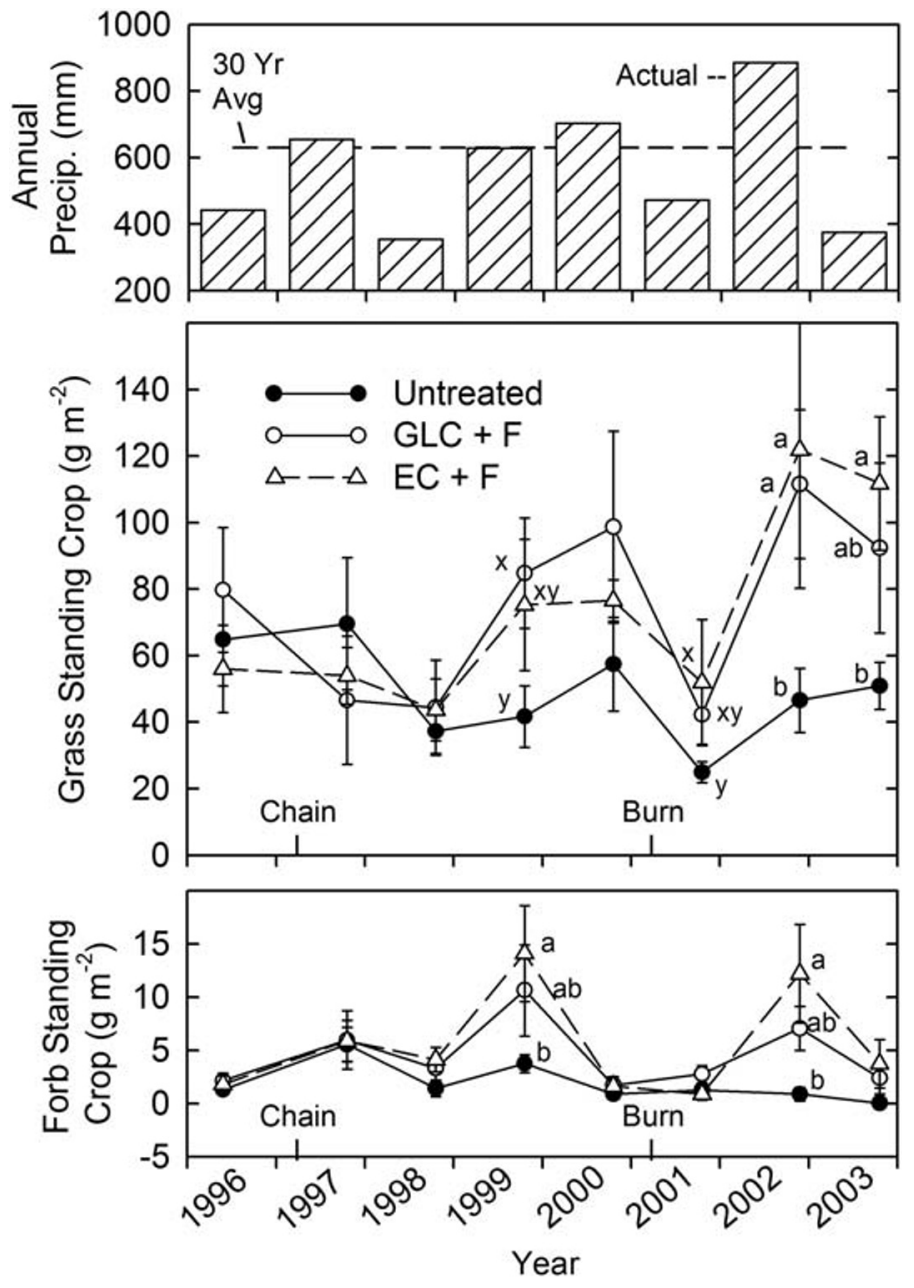

Figure 2. Total annual precipitation averaged over both ranch sites compared to 30-year mean (top), and end-of-growing-season grass standing crop (middle) and forb standing crop (bottom) in response to the 3 treatments. Treatment codes, etc. are same as in Figure 1. Different letters $(\mathrm{a}-\mathrm{c})$ within a year indicate a significant difference at $P<0.05$. Different letters $(x-z)$ within a year indicate a significant difference at $P<0.10$. Years without letters indicate no significant differences among treatments.

untreated by 1999, 3 growing seasons after chaining. After fire treatments in early 2001, grass standing crop was slightly greater in $\mathrm{EC}+\mathrm{F}$ than in untreated at the end of the first growing season postfire (2001), but increased to 2-3 times the untreated in both chain + fire treatments the second and third year postfire. In untreated plots, grass standing crop declined gradually over the course of the study, but most notably in drought years of 1998 and 2001. There was no difference in standing crop between $\mathrm{EC}+\mathrm{F}$ and $\mathrm{GLC}+\mathrm{F}$ treatments during the course of the study, with the exception that there was a greater decline in grass standing crop in the ground-level chaining treatment from 1996 to 1997 , probably the result of scraping effects of ground-level chaining.

End-of-season standing crop within each perennial grass functional group $\left(\mathrm{C}_{3}\right.$ perennial grasses, $\mathrm{C}_{4}$ midgrasses, $\mathrm{C}_{4}$ short grasses) indicated a general trend toward increasing in the treated plots relative to untreated within years, but there were no statistically significant differences (data not shown). 


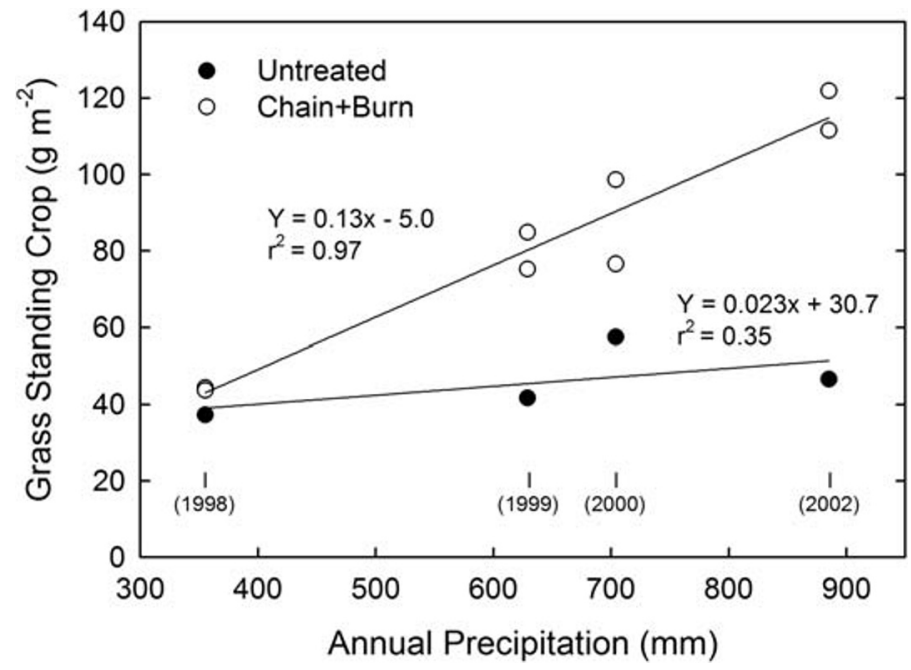

Figure 3. Regression between annual precipitation and end-of-growingseason grass standing crop in treated and untreated rangeland from 1998-2002 (treatment years 1997 and 2001 omitted). Each point represents a treatment mean $(n=4)$. Data from the $\mathrm{GLC}+\mathrm{F}$ and $\mathrm{EC}+\mathrm{F}$ treatments were grouped into the "chain + fire" treatment. Each set of 3 vertical data points is identified by year (in parentheses). Juniper cover was $40 \%-50 \%$ in the control and $<6 \%$ in the treated plots.

Significant differences in standing crop between treatments were only found when all grass functional groups were treated collectively.

End-of-growing-season forb standing crop was similar among all 3 treatments except in 1999 and 2002 when it was greater in the $\mathrm{EC}+\mathrm{F}$ treatment and nearly greater in the GLC + F treatment than the untreated (Fig. 2). Both of these peaks in forb production occurred 2-3 growing seasons after either the chain or the fire treatment but never exceeded $16 \%$ of the total herbaceous standing crop.

A positive linear relationship occurred between annual precipitation and end-of-growing-season grass standing crop (Fig. 3). The slope of the relationship was over 5 times steeper in treated (GLC $+\mathrm{F}$ and $\mathrm{EC}+\mathrm{F}$ combined) than in untreated plots $(0.13$ vs. 0.023$)$.

\section{Herbaceous Cover and Bare Ground}

Pretreatment total grass basal cover ranged from 39\%-40\% among all treatments and remained similar among treatments until 1999, 2 growing seasons after the chain treatments, when cover in the GLC + F showed a trend of being greater than in $\mathrm{EC}+\mathrm{F}$, with untreated intermediate (Fig. 4). This difference did not last more than 1 year, and by 2002, 2 growing seasons postfire, total grass cover was greater in the GLC $+\mathrm{F}$ and slightly greater in the $\mathrm{EC}+\mathrm{F}$ treatments than in the untreated. Over the course of the study, total grass cover only slightly increased from pretreatment levels of $40 \%$ in treated plots and declined from $40 \%$ to $30 \%$ in the untreated.

Among the individual grass functional groups there were no differences in basal cover between treatments throughout the study. $\mathrm{C}_{4}$ perennial midgrasses, $\mathrm{C}_{4}$ perennial short grasses, and $\mathrm{C}_{3}$ perennial midgrasses all showed trends of increasing cover in treated plots over the untreated after the fire treatments (2001-2003), but these were not significant (data not shown).

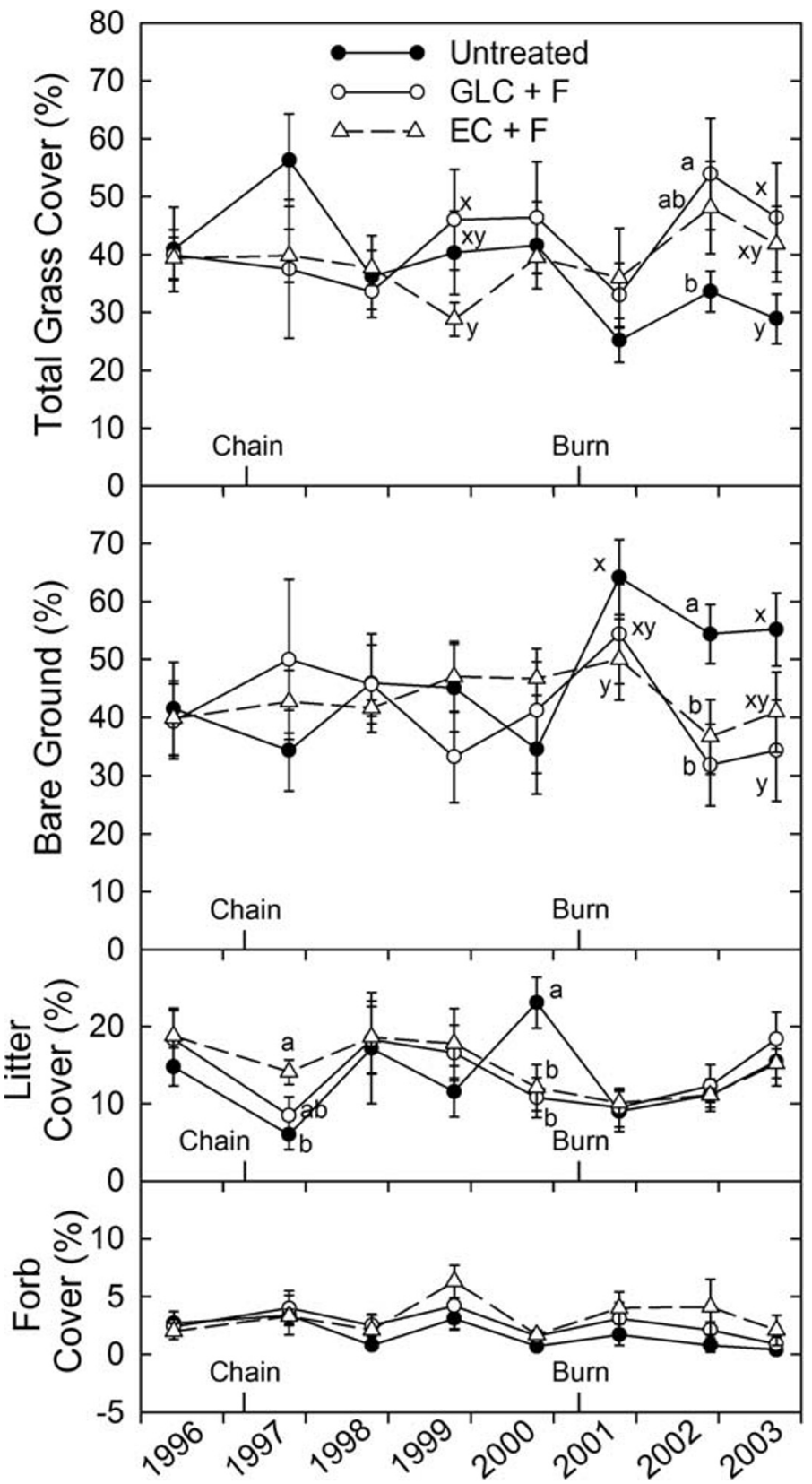

Figure 4. Total perennial grass $\left(\mathrm{C}_{3}+\mathrm{C}_{4}\right)$ basal cover, bare ground, litter, and forb cover in response to chaining and fire treatments. Treatment codes, etc. are same as in Figures 1 and 2.

$\mathrm{C}_{3}$ and $\mathrm{C}_{4}$ annual grass cover was $<1 \%$ in all treatments and years (data not shown).

Bare ground ranged from $39 \%$ to $42 \%$ in all treatments at study initiation and did not change between treatments over the course of the study until the severe drought in 2001 (Fig. 4). At this time, bare ground in the untreated increased from $35 \%$ to $65 \%$ and thereafter remained above $54 \%$. In treated plots, bare ground remained fairly constant from 1996 to 2001, with a slight but not significant increase from fall 2000 to fall 2001 in response to the spring 2001 fire. In the second and third growing seasons following fire (2002 and 2003) bare ground decreased from $50 \%$ to between $34 \%$ and $41 \%$ in both the $\mathrm{GLC}+\mathrm{F}$ and $\mathrm{EC}+\mathrm{F}$ treatments. 
Litter cover ranged from $15 \%$ to $19 \%$ in all treatments at study initiation and remained between $5 \%$ and $23 \%$ during the study (Fig. 4). Litter cover was slightly greater in the chained treatments in fall 1997, 8 months after chaining, but was not different between treatments in other years, except for 2000. In this year, litter was considerably greater in the untreated plots. Forb cover remained less than $7 \%$ in all treatments throughout the study and showed a trend of increasing in the treated plots, especially in the $\mathrm{EC}+\mathrm{F}$ treatment, but differences were not significant (Fig. 4).

\section{DISCUSSION}

\section{Juniper Responses}

The reduction in juniper mortality from 1997 to 2003 was unexpected; we believed the fire treatment 4 years after chaining would increase mortality of this resprouting juniper species over that of chaining alone by killing exposed meristem on trees that had been partly uprooted by chaining. Some uprooted stumps that appeared dead in 1997 may have sprouted between 1997 and 2003, thus lowering the mortality percentage. In addition, herbaceous fuel remained patchy at the time of burning, and a consistent flame front was not achieved. Areas that were initially dense, closed-canopy stands of juniper likely did not grow sufficient herbaceous fuel between 1997 and 2001 for fire to have had an effect on the chained junipers. Low juniper mortality contributed to the observation of no net change in juniper densities during the course of the study. Although the chain + fire treatments did not reduce juniper density, they did reduce tree height and canopy cover such that the competitive effect of juniper was reduced.

\section{Herbaceous Responses}

Differences in grass standing crop between treated and untreated plots was a gradually developing process with significant differences $(P<0.05)$ not occurring until 2002, 6 growing seasons after chaining and 2 growing seasons postfire. Peak absolute values in treated plots of $122 \mathrm{~g} \cdot \mathrm{m}^{-2}$ remained about half of what is found on similar sites in the region that have not been invaded by junipers. Thus, although restoration was evident, the process was very slow. This contrasts with other studies in North America and Australia that show a rapid increase in herbage production following mechanical thinning of the woody overstory (Clary 1971; Watson and Reid 2001).

One reason for the slow increase in standing crop in treated plots may be an even slower rate of increase in grass cover. The observation that there was a trend toward increasing standing crop 3 years after both chain treatments (in 1999) but that there was no matching increase in grass cover in this year suggests that early increases in grass standing crop from chaining alone were because of increased growth within existing grass patches or bunches. Subsequently, the fire treatment may have stimulated recruitment of grass species into bare soil areas and, as such, postfire increases in grass standing crop in 2002 and 2003 were probably due to a combination of increased growth in existing grass patches plus increased recruitment into bare soil areas.

We expected bare ground area to significantly decrease in the treated plots over 8 years, but it did not. We conclude that in a community largely dominated by $\mathrm{C}_{4}$ bunchgrasses, any significant reduction in bare ground would need to originate from recruitment of new plants via seed. Droughts and/or loss of topsoil from erosion may have slowed this process. With these results we fail to reject a portion of Hypothesis 1 that both ground-level chain + fire and elevated chain + fire treatments would facilitate herbaceous restoration by increasing grass production and cover. However, because treatments did not significantly reduce bare ground, we must reject the second portion of our first hypothesis.

Ground-level chaining temporarily reduced grass cover relative to the other treatments the first year postchaining but this effect was gone after 2 years. However, we found no longterm differences in herbaceous production or cover responses between the GLC + F and EC + F treatments. Therefore, we reject Hypothesis 2 that elevated chaining would accelerate herbaceous restoration compared to ground-level chaining.

The slope of the relationship between annual precipitation totals and end-of-growing-season grass standing crop during posttreatment years of 1998-2002 (Fig. 3) was steeper in treated (EC $+\mathrm{F}$ and GLC $+\mathrm{F}$ combined) compared to untreated because high levels of juniper cover in the untreated $(30 \%-50 \%$ vs. $<5 \%$ in treated) likely reduced the ability of grasses to grow in wet years. The sharp decline in grass standing crop in the untreated control during the drought year of 1998, and the relative lack of increase in the untreated compared to both chain + fire treatments during the wet year of 2002 (Fig. 2), suggests that the competitive effect of a dense stand of juniper on grass growth may be greatest during extreme years. These results agree with McPherson and Wright (1990) who found that herbaceous production declined with increasing juniper cover to a greater degree in wet than in dry years. Based on these results, we fail to reject Hypothesis 3 that herbaceous response to precipitation would differ between treated and untreated juniper stands.

Relatively few studies have quantified long-term herbaceous responses following combined (mechanical + fire) treatments of juniper stands. Both Wink and Wright (1973) and Steuter and Wright (1983) found that first year postburn grass production was greater in redberry juniper-dominated stands that were either bulldozed or chained and then burned 4 or 5 years after mechanical treatment. However, neither study measured grass production after the mechanical treatment or for more than 1 year postfire. Recently, an economic modeling study determined that chaining followed by burning in 7-year intervals was an economical method of redberry juniper control (Johnson et al. 1999). Increased livestock production (cattle) from increased herbaceous production was used as the basis to calculate net present values of the investment in brush control treatments over a 30-year period. However, these projections were not based on long-term quantification of herbaceous responses to chaining + fire. Results from our study may aid in future economic modeling efforts.

Other studies worldwide have used combinations of treatments to manage woody plant encroachment, but because of the high costs of mechanical treatments, combinations often involve an initial herbicide treatment prior to burning (Noble et al. 1991). Bulldozing + fire has been used to combat Mimosa pigra invasion and increase grass production in Australia (Paynter and Flanagan 2004). However, in South Africa, a "fell and burn" strategy to control the invasive Hakea sericea 
damaged the graminoid understory because the added fuel from felling these woody plants caused a very intense fire (Holmes et al. 2000). In this study, burning was applied only 1 year after mechanical felling and some of that concern may be abated in a study such as ours where burning occurred 4 years after chaining. Another concern of mechanical clearing followed by burning is potential acceleration of nitrogen loss through leaching, but Weston and Attiwill (1996) found no such leaching following clearing and burning old-growth Eucalyptus regnans forests in Australia.

Mechanical clearing of woody plants often stimulates recruitment of woody plant seedlings. Thus, for mechanical clearing to be successful, a subsequent treatment such as fire may be needed to limit woody recruitment. This has been noted in North America (Steuter and Wright 1983; Rasmussen and Wright 1989) and Australia (Hodgkinson and Harrington 1985).

\section{Postfire Succession}

Postfire succession models developed from observations of juniper-dominated ecosystems in the Intermountain (United States) region (Barney and Frischknecht 1974; Everett and Ward 1984; West and van Pelt 1987) portray a progression from annuals to perennial grasses to grass/shrub mix to juniper dominance over time. In these models, fires kill the juniper overstory, because these juniper species do not resprout. Annual forbs increase rapidly in the immediate postfire years and are later replaced by perennial grasses and small shrubs (Koniak 1985; Miller et al. 2000). Juniper encroachment from newly emerging seedlings gradually gains over time and, as junipers regain dominance, herbaceous diversity and perennial grass production decline. Postfire increase to the point of dominance would be expected to occur much earlier (perhaps within 20 years) with a resprouting species such as redberry juniper (Ansley and Rasmussen 2005).

Results from the current study disagree somewhat with the juniper succession models described; we did not find a strong shift toward forbs in the first few years postfire. The site remained dominated by a limited number of $\mathrm{C}_{4}$ perennial midgrass species. The large amount of bare ground coupled with severe droughts probably limited recruitment of forbs and other grass species. It should be noted that, because we monitored postfire responses for only 3 years, we have no basis to compare our study with the projected intermediate succession stages in the Barney and Frischknecht (1974) model. In addition, annual grasses are not a significant problem in juniper-dominated regions of the southern prairie and, as such, the potential for an annual grass-mediated shift in the succession process such as is found in the Intermountain area (Miller and Rose 1999) is currently low in the southern Great Plains.

\section{MANAGEMENT IMPLICATIONS}

Timing of the fire treatment at 4 years after chaining mimicked a typical situation for such a combined treatment management scenario in the southern Great Plains (Rasmussen and Wright 1989; Ansley and Rasmussen 2005). However, our results suggest that complete restoration of juniper-dominated regions with depleted soils, even under such combined treatments, does not occur rapidly. Condition of the resource prior to treatment, in particular soil health and herbaceous composition and cover, as well as posttreatment precipitation patterns are key variables in determining rates of restoration (Tausch and Tueller 1977; Everett and Ward 1984). Because juniper domination tends to increase the amount of bare ground in addition to reducing growth of existing herbaceous patches, posttreatment recovery is also dependent on the rate of recruitment of herbaceous plants into bare soil areas (Miller et al. 2000).

One revealing element of this study was the observation of the progressive negative impact of increasing juniper domination in the untreated control on the herbaceous community. During the droughts of 1998 and 2001, grass production and cover declined sharply. Coupled with this, responses in the untreated plots in 2002 revealed that the grass community did not make significant gains during wet years. A long-term pattern of herbaceous species losing ground in drought years and failing to recover in wet years suggests a trend toward degradation. These responses imply that, in the southern prairie, a "do nothing" management perspective with respect to juniper-dominated rangelands (i.e., no anthropogenic disturbances such as chaining or prescription burning) is not an acceptable option.

\section{ACKNOWLEDGMENTS}

The authors are grateful for the cooperation and funding of an anonymous foundation, the land provided by the Johnson JJ Ranch and the Glen Halsell Ranch, Crowell, and to Billy Kinney Conservation Contractor, Paducah. We thank Betty Kramp, David Jones, Gerral Schulz, Bobby Idol, Tim Tunnell, and Matt Angerer for their assistance in sampling and treatment implementation.

\section{LITERATURE CITED}

Ansley, R. J., W. E. Pinchak, W. R. Teague, B. A. Kramp, and D. L. Jones. 2004. Longterm grass yields following chemical control of honey mesquite. Journal of Range Management 57:49-57.

Ansley, R. J., W. E. Pinchak, and D. N. Ueckert. 1995. Changes in redberry juniper distribution in northwest Texas. Rangelands 17:49-53.

Ansley, R. J., and G. A. Rasmussen. 2005. Managing native invasive juniper species using fire. Weed Technology 19:517-522.

ARCHER, S. 1990. Development and stability of grass/woody mosaics in a subtropical savanna parkland, Texas, U.S.A. Journal of Biogeography 17:453-462.

Archer, S., D. S. Schimel, and E. A. Holland. 1995. Mechanisms of shrubland expansion: land use, climate or $\mathrm{CO}_{2}$ ? Climate Change 29:91-99.

Asner, G. P., A. J. Elmore, L. P. Olander, R. E. Martin, and A. T. Harris. 2004. Grazing systems, ecosystem responses, and global change. Annual Review of Environment and Resources 23:261-299.

Barney, M. A., And N. C. FrischkneCht. 1974. Vegetation changes following fire in the pinyon-juniper type of west-cental Utah. Journal of Range Management 27:91-96.

Barnitz, J. A., Jr., S. M. Armentrout, V. W. Howard, JR., R. D. Pieper, and G. M. SouthWARD. 1990. Vegetational changes following two-way cabling of pinyonjuniper in south-central New Mexico. New Mexico Agricultural Experiment Station Bulletin 749:1-36.

BelSkY, A. J. 1994. Influences of trees on savanna productivity: tests of shade, nutrients, and tree-grass competition. Ecology 75:922-932.

BonHam, C. D. 1989. Measurements for terrestrial vegetation. New York, NY: John Wiley \& Sons. $338 p$.

BuRKhardT, J. W., and E. W. TISDALE. 1976. Causes of juniper invasion in southwestern Idaho. Ecology 57:472-484. 
ClaRY, W. P. 1971. Effects of Utah juniper removal on herbage yields from Springerville soils. Journal of Range Management 24:373-378.

ENGLE, D. M. 1985. Effects of eastern redcedar on range forage and livestock production. In: R.F. Wittner and D.M. Engle (EDS.). Proceedings-Eastern Redcedar in Oklahoma Conference; 20 February 1985; Stillwater, OK Oklahoma State University Cooperative Extension Service E-849. p 53-60.

Everett, R. L., AND K. WaRD. 1984. Early plant succession on pinyon-juniper controlled burns. Northwest Science 58:57-68.

Gehring, J. L., AND T. B. Bragg. 1992. Changes in prairie vegetation under eastern red cedar (Juniperus virginiana L.) in an eastern Nebraska bluestem prairie. American Midland Naturalist 128:209-217.

Grover, H. D., AND H. B. Musick. 1990. Shrubland encroachment in southern New Mexico, U.S.A.: an analysis of desertification processes in the American southwest. Climatic Change 12:305-330.

Hodgkinson, K. C., And G. N. HarRington. 1985. The case for prescribed burning to control shrubs in eastern semi-arid woodlands. Australian Rangeland Journal 7:64-74.

Holmes, P. M., D. M. Richardson, B. W. Van Wilgen, and C. Gelderblom. 2000. Recovery of South African fynbos vegetation following alien woody plant clearing and fire: implications for restoration. Austral Ecology 25:631-639.

Johnson, P., A. Gerbolini, D. Ethridge, C. Britton, and D. Ueckert. 1999. Economics of redberry juniper control in the Texas Rolling Plains. Journal of Range Management 52:569-574.

Johnson, T. N. 1962. One-seed juniper invasion of northern Arizona grasslands. Ecological Monographs 32:187-207.

KonIAK, S. 1985. Succession in pinyon-juniper woodlands following wildfire in the Great Basin. Great Basin Naturalist 45:556-566.

Kramp, B. A., R. J. Ansley, and T. R. Tunnelt. 1998. Survival of mesquite seedlings emerging from cattle and wildlife feces in a semi-arid grassland. The Southwestern Naturalist 43:300-312.

McPherson, G. R., And H. A. Wright. 1990. Effect of cattle grazing and Juniperus pinchottii canopy cover on herb cover and production in west Texas. American Midland Naturalist 123:144-151.

Mileter, R. F., AND J. A. Rose. 1999. Fire history and western juniper encroachment in sagebrush steppe. Journal of Range Management 52:550-559.

MilleR, R. F., T. J. SveJCAR, and J. A. Rose. 2000. Impacts of western juniper on plant community composition and structure. Journal of Range Management53:574-585.

[NOAA] National Oceanic and Atmospheric Administration. 2003. Climatological data annual summary-Texas. Rocket Center, WV: NOAA. $75 \mathrm{p}$.

Noble, J. C., N. D. MacLeod, J. A. Ludwig, and A. C. Grice. 1991. Integrated shrub control strategies in Australian semi-arid woodlands. In: 6th International Rangeland Congress, Montpellier, France. Denver, CO: Society for Range Management. p 846-849.

Paynter, Q., and G. J. Flanagan. 2004. Integrating herbicide and mechanical control treatments with fire and biological control to manage an invasive wetland shrub, Mimosa pigra. Journal of Applied Ecology 41:615-629.
Rasmussen, G. A., and H. A. Wright. 1989. Succession of secondary shrubs on Ashe juniper communities after dozing and prescribed burning. Journal of Range Management 42:295-298.

Rippel, P., R. D. Pieper, and G. A. Lymbery. 1983. Vegetational evaluation of pinyonjuniper cabling in south-central New Mexico. Journal of Range Management 36:13-15.

SAS [Computer Program]. 1988. Statistical Analysis Systems, version 6.03. Cary, NC: SAS Institute, Inc.

Scholes, R. J., ANd S. R. Archer. 1997. Tree-grass interactions in savannas. Annual Review of Ecology and Systematics 28:517-544.

Steuter, A. A., and C. M. Britton. 1983. Fire induced mortality of redberry juniper [Juniperus pinchotii Sudw.]. Journal of Range Management 36: 343-345.

Steuter, A. A., and H. A. Wright. 1983. Spring burning effects on redberry juniper-mixed grass habitats. Journal of Range Management 36: 161-164.

Tausch, R. J., and P. T. Tueller. 1977. Plant succession following chaining of pinyon-juniper woodlands in eastern Nevada. Journal of Range Management 30:44-49.

Ueckert, D. N., R. A. Phillips, J. L. Petersen, X. B. Wu, and D. F. Waldron. 2001. Redberry juniper canopy cover dynamics on western Texas rangelands. Journal of Range Management 54:603-610.

Van Auken, 0. W. 2000. Shrub invasions of North American semiarid grasslands. Annual Review of Ecology and Systematics 31:197-215.

Watson, C., AND N. Reid. 2001. Herbage response to thinning of eucalypt regrowth. Natural Resource Management 4:16-21.

West, N. E., and N. S. van Pelt. 1987. Successional patterns in pinyon-juniper woodlands. In: R. L. Everett [ComplLeR], Proceedings-Pinyon-Juniper Conference; 13-16 January 1986; Reno, NV. Ogden, UT: USDA Forest Service Intermountain Research Station. p 43-52.

Weston, C. J., AND P. M. Attiwill. 1996. Clearfelling and burning effects on nitrogen mineralization and leaching in soils of old-age Eucalyptus regnans forests. Forest Ecology and Management 89:13-24.

Wiedemann, H. T. 2004. Mechanical brush management-Current state of the art. Chapter 3. In: W. T. Hamilton, A. McGinty, D. N. Ueckert, C. W. Hanselka, and M. R. Lee [EDs.]. Brush Management: Past, Present, and Future. College Station, TX: Texas A\&M University Press. p 33-46.

Wiedemann, H. T., And B. T. Cross. 1996. Draft requirements to fell junipers. Journal of Range Management 49:174-178.

Wiedemann, H. T., J. E. Slosser, and R. J. Ansley. 2005. Tabanus abactor Philip responses to chaining and burning redberry juniper stands. Southwestern Entomologist 30:203-214.

Wink, R. L., AND H. A. WriGHT. 1973. Effects of fire on an Ashe juniper community. Journal of Range Management 26:326-329.

Wright, H. A., And A. W. Bailey. 1982. Fire Ecology. New York, NY: John Wiley and Sons, Inc. $501 \mathrm{p}$. 